\title{
BIOGEOCHEMISTRY OF STABLE CARBON ISOTOPES
}

\author{
E. T. DEGENS
}

Department of Chemistry and Geology

/ The Woods Hole Oceanographic Institution

Woods Hole, Mass.'

Historical background
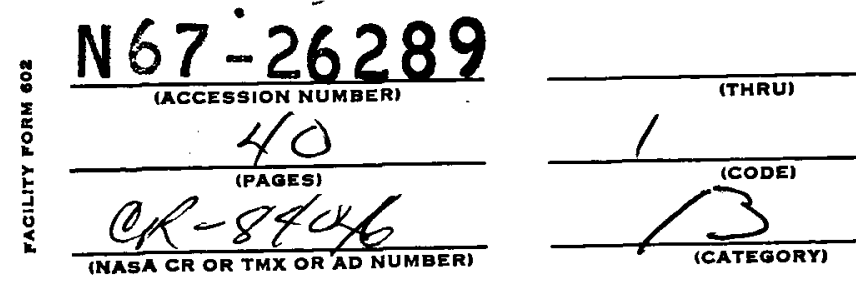

In 1947, in his classical paper on the thermoaynamıc properties of isotopic substances, H. C. Urey l/ laid the foundation of modern isotope geochemistry. At the same time, A. 0. Nier/ designed a new mass spectrometer which allowed the measurement of small differences in isotope abundance ratios. A modification in the Nier-type mass spectrometer and a refinement

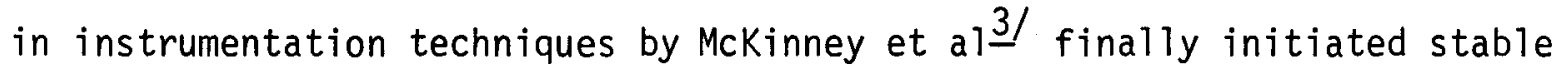
isotope studies of the type that will be discussed in this review.

The early work done in the field of stable carbon isotope biogeochemistry can be described as a reconnaissance survey, because little was actually known at that time of the $c^{13}$ content in the various biological and geological materials. This introductory chapter of isotope biogeochemistry was largely written by Baertschi $4 /$, Craig $\frac{5}{}$, Landergren $\frac{6}{}$, Nier and

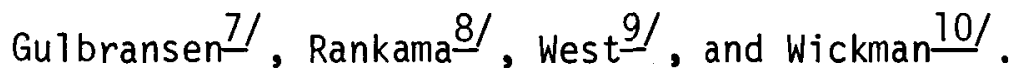

A significant breakthrough in isotope research started about 1960. Park and Epstein11/ 12/ and Abelson and Hoering 13/ discovered that photosynthetic carbon reduction may lable the various metabolic products differently. Both groups of authors realized the significance of this observation for studies on the biosynthetic pathways of carbon and the geological carbon cycle. 
Applying data by Bigeleisen $14 /$ on the relative reaction velocities of isotopic molecules, Silverman $15 /$ and Sackett et a1. $16 /$ showed that thermal cracking of carbon-carbon bonds in various organic materials may introduce isotope fractionation.

The present trend is to analyze pure and chemically well-defined carbon compounds, and to study the isotope relationships between co-existing organic phases. This feature is analogous to the geochemist's approach, who is generally more interested in the element or isotope composition of individual minerals than in the chemistry of a homogenized rock powder.

\section{Scope of studies}

There are a great number of specific problems, both in the field of biology and geology, where carbon isotope data can be used profitably. The significant application to biology lies in the outline of biosynthetic pathways through a comparison of isotope ratios in discrete biochemicals. Inasmuch as organisms can be studied in their natural habitat, the advantage of stable carbon isotope methods over radiocarbon techniques becomes evident.

In geology on the other hand we are principally dealing with two sets of problems. The first one is concerned with the diagenetic fate of organic matter through geologic time; the second one tries to gain more insight into the nature of primordial carbon in terrestrial and extraterrestrial bodies.

As we proceed in our discussion, there will be ample opportunity to see the intimate relationship between living and fossil carbon-containing compounds. Furthermore, we will notice that information on the distribution 
of carbon isotopes in all biological and geological material is essential to understand the complex biogeochemical cycle of carbon through time and space.

\section{METHODS OF ANALYSIS}

Combustion system for organic matter

The working gas of mass spectrometers is usually carbon dioxide. Thus, samples require conversion of organic carbon to carbon dioxide, and purification of the carbon dioxide from any contaminating gas contained in the system. This is accomplished following a procedure outlined by craig $5 /$.

\section{Figure 1}

The steps involved in the combustion of organic matter are illustrated in Figure 1. The operation starts by placing the sample--if solid--in an alundum boat in quantities sufficient to provide about 10-15 cc of carbon dioxide. Carbonate-containing samples require acidification prior to combustion. The boat is subsequently placed in a quartz-combustion tube which is half-filled with copper oxide. After the system is closed and pumped down to high vacuum, oxygen is admitted and combustion carried out to completion at temperatures in the neighborhood of $900^{\circ} \mathrm{C}$. During combustion, the generated gases are continously recycled via an electrically operated Toepler pump to secure a total conversion of carbon monoxide to carbon dioxide; a nitrogen cooled trap provides a simultaneous collection of carbon dioxide. 
Following a suggestion of Sackett and Thompson-17/, the $\mathrm{CO}_{2}$ is passed over hot $\left(500^{\circ} \mathrm{C}\right)$ manganese dioxide and copper to remove contaminating sulfur and nitrogen oxides. A set of cooled traps, filled with acetonedry ice and liquid nitrogen, finally separates the carbon dioxide from any water or gas contaminant. The carbon dioxide yield can subsequently be measured in a calibrated manometer, after which the gas is transferred to a sample tube and ready for mass spectrometer analysis.

Where the sample is fluid, a variety of techniques have been proposed for the extraction of the carbon compounds $\underline{5 / 18 /} \underline{19 / 20 /}$.

\section{Mass spectrometer analysis}

The basic details of the commonly used mass spectrometer in stable isotope work have been described by Nier $2 /$. Improvements of the design $\underline{3}$ have increased the precision of the Nier instrument by more than 50 percent.

The instrument is a $60^{\circ}$ sector-type mass spectrometer and contains a double collecting system. The analysis starts by feeding the $\mathrm{CO}_{2}$ sample via a small gas leak into the mass spectrometer source which ionizes the gas to $\mathrm{CO}_{2}^{+}$. The ions, after being accelerated in an electrostatic field and focused along a single ion beam, have to pass through a magnetic analyzer where they are separated according to their mass. The resolved ion-beams, upon hitting a collector, become neutralized. The electric current thereby released is electronicaliy amplified and recorded on a potentiometer.

The $c^{13} / c^{12}$ ratio is determined by comparing mass $45\left(c^{13} 0^{16}{ }^{16}\right)$ with mass $44\left(C^{12} 0^{16} 0^{16}\right)$. Variations in the mass $45 / 44$ ratio are measured relative to an isotopically known standard gas. Inasmuch as a 
magnetically operated valve inlet-system allows a switchover from the standard $\mathrm{CO}_{2}$ to the unknown $\mathrm{CO}_{2}$ gas in a matter of seconds, a rapid comparison of carbon isotope ratios of both gases under the same mass spectrometer source conditions is made possible.

\section{Isotope standards}

In the 1 iterature, the $c^{13} / c^{12}$ ratios are reported in a number of different ways. This is unfortunate because it makes it more difficult to compare the results of the various authors. The reference scales most frequently used include the Stockholm, NBS (National Bureau of Standards) Nos. 20, 21, 22, We11 ington, Nier-Solenhofen 1 imestone, Basel, and PDB-Chicago standards. In order to be consistent throughout this survey, it was decided to select the most commonly used standard, i.e., the PDB-Chicago standard as a reference scale. All data reported differentiy have been adjusted to the PDB standard using the appropriate conversion factors $21 / 15 /$ in order to facilitate comparison of published information.

The canbon isotopere reported as $\delta$-values, which are deviations in parts per thousand (per mi1) of the $c^{13} / c^{12}$ ratios of the samples from that of the $\mathrm{CO}_{2}$ obtained from the belemnite standard (Peedee Formation, Upper-Cretaceous, South Carolina), abbreviated PDB-standard, used by the University of Chicago group $5 / 21 /$. $\delta$-values are defined by the formula:

$$
\begin{aligned}
\delta C^{13} & =\left(\frac{R}{R_{S}}-1\right) \times 1000 \\
R & =C^{13} / C^{12} \text { ratios in the sample } \\
R_{S} & =C^{13} / C^{12} \text { ratio in the standard }
\end{aligned}
$$


Appropriate corrections for the $0^{17}$ contributions to the mass $45-$ beam, the mixing error of smaple and standard at the analyzer tube inlet, and the tailing of the mass 44 peak under the mass 45 peak are commonly applied $21 /$. The precision of the reported analyses is \pm 0.2 per mil or better.

\section{Sample material}

This review is based on more than 5000 carbon isotope data which have been largely obtained from the literature. Unpublished results of more than 500 analyses are also included in the figures; they have kindly been made available by K. 0. Emery, R. L. Guillard, J. A. Hellebust, J. M. Hunt, W. M. Sackett, H. G. Trüper, and S. W. Watson.

The individual samples have been grouped into systematic classes of compounds and have been plotted in form of cumulative frequency diagrams (2 sigma range) to summarize the informations in a comprehensive form. The diagrams can be found in the appendix.

\section{Photosynthes is}

Essentially all living matter is directly (plants) or indirectly (animals) a product of photosynthesis. Let us therefore, briefly consider the main avenues of carbon reduction during this process and earmark possible isotope fractionation barriers. For a comprehensive ac-

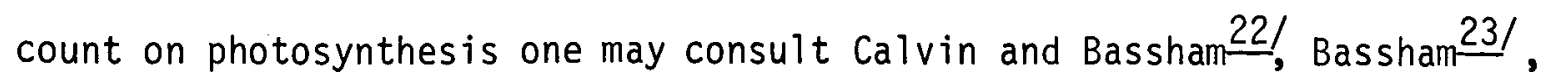
and Bonner and Varner $24 /$.

1. Environmental effects

Plants extract inorganic carbon from two sources, (1) atmospheric 
carbon dioxide, and (2) dissolved $\mathrm{CO}_{2}$ and bicarbonate in the hydrosphere. Whereas ocean and atmosphere are close to isotopic equilibrium, fresh waters are generally in disequilibrium with air $\mathrm{CO}_{2}$ as a result of exces-

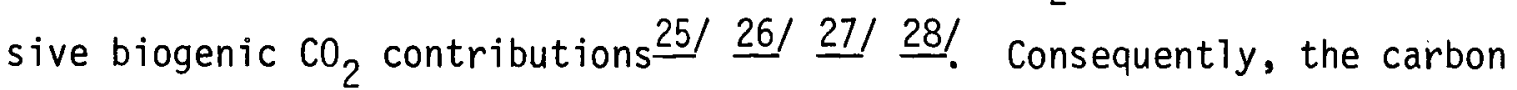
in the atmosphere and in fresh waters is generally enriched in $c^{12}$ relative to carbon in the marine envrionment.

There is another isotope fractionation factor which may further enhance the $\delta C^{13}$ gap between terrestrial and marine organisms. It is well established that in gas molecules the velocities of isotopic species are equal to the inverse square root of the molecular weights. For carbon dioxide we can write:

$$
\frac{\text { Velocity }\left(c^{12} 0^{16_{0}}{ }^{16}\right)}{\text { Velocity }\left(c^{13} 0^{16} 0^{16}\right)}=\sqrt{\frac{45}{44}}=1.011
$$

This implies that there are 1.1 percent more frequent collisions of mass $44 \mathrm{CO}_{2}$ with a photosynthesizing leaf as compared with mass $45 \mathrm{CO}_{2}$ encounters.

These facts infer that land plants may be substantially enriched in $c^{12}$ relative to marine plants and preliminary data on the carbon isotope distribution in marine and terrestrial organisms seemed to support this inference $5 /$. Recently, however, more information on marine phytoplankton has become available $e^{29 /}$ and there is no longer a difference recognizable in the $\delta C^{13}$ range of marine plankton and common land plants. In view of the apparent $\mathrm{C}^{12}$ advantage of land plants, the new results represent a major puzzle.

Figure 2 
It has been suggested $30 /$ that environmental effects may account for some of the isotope fractionations observed in organisms. Recent data $\underline{29 /}$ showing pronounced differences between warm water (10w latitudes) and cold water (high latitudes) marine plankton populations, underlined this idea. It may be implied that either differerences in water temperature, length of day, or in both factors are responsible for this phenomenon.

In order to test possible effects of water temperature and respiration characteristics on the $c^{13} / \mathrm{C}^{12}$ ratio of marine plants, the carbon isotope fractionation pattern of laboratory cultured plankton, grown under

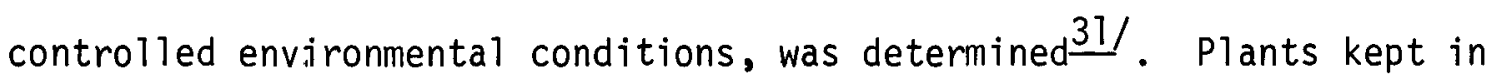
darkness for a few days change isotopically by as much as 5 per mil (Figure 2). Concerning water temperature, a 7 per mil difference was noticable between cultures grown at $10^{\circ}$ and $30^{\circ} \mathrm{C}$. In one experiment, $\mathrm{CO}_{2}$ was admitted in large quantities to a growing plant population, resulting in a lowering of the $\mathrm{pH}$ to about 6 . In this case no temperature effects were noticable - and the isotope values at all temperature levels corresponded to those found in plankton of cold water environments. These results were tentatively interpreted to mean that in natural habitats cold water marine plankton utilize largely free $\mathrm{CO}_{2}$, whereas warm water plankton prefer a $\mathrm{C}^{13}$ enriched bicarbonate source.

\section{Figure 3}

It is too early to elaborate more extensively on other possible environmental effects. The published isotope record is too scanty yet. 


\section{Metabolic effects}

The first reaction of carbon dioxide reduction in photosynthes is is a carboxylation reaction involving ribulose-1, 5-diphosphate and 3-phosphoroglyceric acid. From here a stepwise formation of various sugars takes place and the monosaccharide conversion via phophorylated derivatives will proceed. The available data suggests, that a subsequent polysaccharide synthesis from mixtures of sugar nucleotides will not result in a significant rearrangement of the individual carbon skeletons.

Let us now examine the carbon isotope relationship in this portion of the photosynthetic carbon reduction cycle. Park and Epstein 11/ 12/ have shown that the enzymatic $\mathrm{CO}_{2}$ fixation leading to $\mathrm{PGA}$ is accompanied by a max. 17 per mil enrichment in $C^{12}$. They concluded that this carboxylation step is the major metabolic effect controlling the carbon isotope composition of the plant as a whole. It was further suggested that except for the chloroform-extractable lipids, no other major biochemical compound is labeled isotopically different from the total plant. Based on work by Degens et al. 32/ different carbohydrates in an organism may show different degrees of $\mathrm{C}^{12}$ - enrichment relative to the starting $\mathrm{CO}_{2}$. Although individual sugars are spread over a wide $\delta C^{13}$ range, total sugars are isotopically identical to the plant as a whole.

The biosynthesis of amino acids follows a rather complex pattern. Principally, intermediates of the glycolytic pathway (e.g. phosphoenolpyruvate, pyruvate) and the tricarboxylic acid cycle (e.g. $\alpha$-ketoglutarate, oxalacetate, glyoxalate) supply the necessary carbon skeletons from which by reductive amination or transamination, amino acids arise, In view of 
the numerous ways at which carbon can be arranged in the TCA - cycle, there is ample opportunity of carbon isotope fractionation.

Differences in $\delta C^{13}$ between the various amino acids in a protein hydrolyzate are vividly displayed in a study by Abelson and Hoering $\underline{13 /}$. The internal $\delta \mathrm{C}^{13}$ variations cover a range of about 17 per mil. Most enriched in $\mathrm{C}^{13}$ are serine, threonine, glycine and aspartic acid, whereas the leucines and aromatic amino acids contain more $c^{12}$. Of further significance is the observation that the carboxyl functions of amino acids are generally enriched in $\mathrm{C}^{13}$ by as much as 20 per mil relative to the remainder of the molecule. This characteristic has great importance in the evaluation of isotope data from ancient sediments. The internal isotope fluctuations in the amino acids is not reflected in the $\delta \mathrm{C}^{13}$ of the total protein which actually exhibits the same $\delta C^{13}$ content ab the associated carbohydrate fraction. This implies that under conditions of steady photosynthesis, the material balancerof carbon isotopes will always remain a constant; in most instances, the constant will be determined at the RuDPPGA barrier.

Lignin is a major biochemical compound in higher plants, but simple intermediates, e.g. hydroxybenzoic acids, are known from many primitive organisms. The theory has been advanced that certain cinnamic acididerivatives are closely linked with the respiration of the cell, instead of being only physical impregnations of the maturing cell. The starting point of al1 phenylpropanoid compounds is either phenylalanine or tyrosine. Since these two amino acids belong to the ones most enriched in $\mathrm{C}^{12}$, this characteristic will be reflected in the lignin fraction. Of colurse, if the lignin fraction of a plant represents 50 percent or more of the total 
organic matter, the isotope difference to the other biochemicals present will be reduced for reasons of material balance.

The synthesis of lipid compounds involves the oxydation of pyruvate to acetyl coenzyme $A$ and carbon dioxide. From acetyl CoA the formation of the various lipids proceeds. It has been demonstrated by many investigators, e.g. 11/ 12/ 15/ that lipid materials tend to be enriched in $\mathrm{c}^{12}$ by several per mil relative to the plant organic matter as a whole. Parker ${ }^{33 /}$ has extended this knowledge by showing that the maximum fractionation between the individual fatty acids of an organism can amount to 4 per $\mathrm{mil}$, and that different organisms display various orders of $\mathrm{C}^{12}$ enrichment in lipids, i.e. about 4 to 15 per mil relative to the total plant.

There is another interesting aspect of lipid isotope chemistry worth mentioning. It was observed- $\underline{11 /} \underline{29} /$ that an increase in lipids results in a lowering of the $\delta C^{13}$ difference between lipid fraction and total plant. This is probably linked to the glyoxylate cycle which is responsible for the conversion of lipids to carbohydrates.

The major steps of carbon isotope fractionation during photosynthesis are enumerated below. The Roman numerals I to VII indicate the positions where the principal fractionation barriers exist (numbers in parenthesis refer to the maximum fractionation in terms of $\left.\delta \mathrm{C}^{13}\right)$ :

I. Inorganic-organic boundary effects (uptake of $\mathrm{CO}_{2}$ by the plant cytoplasm)

II. Carboxylation at the RUDP-PGA-level

III. Sugar interconversions

IV. Amino acid interconversions

V. Respiration

VI. Fatty acid interconversions

VII. Lipid-carbohydrate conversions 
Reference body is sea water bicarbonate or atmospheric $\mathrm{CO}_{2}$. A change in $\delta C^{13}$ at step I is largely a function of environment (water vs. air), and in the case of marine plants it is further controlled by water temperature. The total $\delta C^{13}$ range of step II is 17 units. This represents the maximum fractionation at the ribulose-1, 5-diphosphate/3-phosphoroglyceric acid level1:1! A brief outline of the photosynthetic carbon fractionation at steps three to six has already been presented in our discussion. It is noteworthy that the $\delta \mathrm{C}^{13}$ in cellulose and lignin will remain unaltered since these compounds do not participate actively in the metabolic turnover of carbon. The glyoxylate cycle (step VII), counteracts the $\mathrm{C}^{12}$-enrichment introduced during respiration and 1 ipid formation, by converting fats into carbohydrates. A further isotope homogenization may be accomplished via the glycolytic pathway which involves the degradation of hexose to pyruvate (pentose shunt pathway), or via the tricarboxylic acid cycle which acts as an incinerator for carbon skeletons. As a consequence of these effects, $\delta C^{13}$ differences between coexisting biochemical compounds become less pronounced.

Finally, the sum of the $\delta C^{13}$ drops across the various barriers must be matched by an increase in $\delta C^{13}$ at some other points. Zero potential is obtained under steady state photosynthesis by translocation of $\mathrm{CO}_{2}$ during assimilation, and the removal of $\mathrm{CO}_{2}$ during respiration; the $\mathrm{CO}_{2}$ hereby released from the system is enriched in $\mathrm{\delta c}^{13}$.

Figures 4 and 5 
The isotope composition in various types of living matter have been summarized in Figures 4 and 5 . The diamond-shaped figures represent the 1 sigma values and are obtained from the more detailed diagrams included in the appendix.

Studies on some marine chemautotrophs have indicated 34 / that they too follow the reductive pentose phosphate cycle. Their source of carbon and energy is solely carbon dioxide and ammonia, respectively. Inasmuch as these organisms are generally considered the most probable precursors of photosynthetic plants, their interest for biogeochemical studies is apparent. The degree of $\mathrm{C}^{12}$-enrichment in these nitrifying bacteria is astounding; there is about twice the fractionation generally observed in common marine plants. We presently do not know the reason for this characteristic.

In contrast, marine sulfate reducers, grown on yeast and sodium lactate, are isotopically only slightly different from their carbon sub-

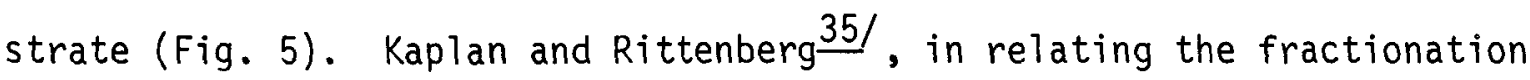
effects to the carboxyl function of lactate, observe a preferential fixation of $\mathrm{C}^{12}$ in sulfate reducing bacteria by a few per mil.

\section{ISOTOPE DISTRIBUTION IN SEDIMENTS}

\section{Recent sediments}

Organic matter in recent sediments has about the same isotopic composition as the organisms living in the environment of deposition. The mean $\delta C^{13}$ of fresh water sediments amounts to -25 , whereas marine muds are generally 5 per mil heavier. Only the sediments deposited in river estuaries show a terrestrial influence and $\delta C^{13}$ gradations can frequently 
be observed. To illustrate the type of gradation pattern that may occur, the $\delta C^{13}$ in near-shore sediments from the Mississippi Sound area is pre-

Figure 6

sented in Figure 6 . The systematic decrease in $\mathrm{C}^{12}$ with increasing distance from the shore line can either be attributed to the lesser influence of land derived organic detritus, or the diminishing effect of light fresh water bicarbonate.

In comparing deep sea sediments with shelf deposits, the similarity in $\delta C^{13}$ values is striking and can only mean that contributions of organic debris from land are of minor significance as soon as we leave the immediate environs of the river inlets, (Fig. 7).

Figure 7

Bacterial populations and burrowing organisms will not grossly modify the $\delta C^{13}$ of recent sediments. Of course, their activities will result in metabolic waste products, some of which subsequently give rise to so-called humic materials. These compounds, however, are isotopically not widely remote from the original biochemicals. During the process of fermentation and decomposition, carbon dioxide and methane of widely different

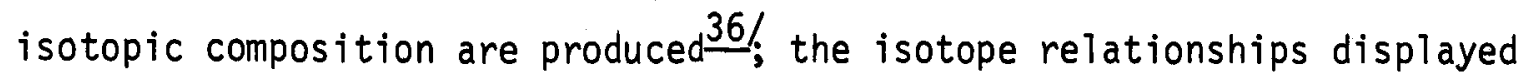
in such a system are illustrated in Figure 17 (see appendix).

In conclusion, the $\delta C^{13}$ in recent sediments is compatible with the general biological and geological viewpoint that the bulk of the organic debris contained in sedimentary deposits is derived from the local 
biological populations. Contributions of fresh water organic matter to marine environments are negligable, and substantially restricted to the small amounts of adsorbed organics on detrital clay minerals.

\section{Ancient sediments}

After the major nutrients such as proteins or non-cellulosic carbohydrates are eliminated from sediments largely by action of microorganisms or burrowing animals, the further diagenetic degradation of organic matter is that of a slow inorganic maturation. This process essentially involves the reduction in functional groups, breaking of carbon-carbon bonds, and a reorganization of the resulting reaction products. Given sufficient time, all fossil organic matter will eventually end up as $\mathrm{CO}_{2}$, methane, and graphite. The question immediately arises: what does this trend mean for the carbon isotope composition in the various intermediate compounds?

It is well established, e.g. 14/ that the substitution of a heavy for a light isotope lowers the vibrational frequencies and the zero point energy of a chemical bond. Consequently, to break a $c^{12}-c^{12}$ bond should require less energy than to part a $\mathrm{C}^{13}-\mathrm{C}^{12}$ bond. Since energy differences become more effective as the carbon-carbon bond dissociation energy in organic molecules decreases, the extent of carbon isotope fractionation will depend on the terminal bond dissociation energies and therefore, vary accordingly.

Other factors important in the diagenetic fractionation of carbon isotopes include the preferential el imination of $c^{13}$-rich compounds such as proteins or carbohydrates in the early stages of diagenesis. Furthermore, a decarboxylation will cause a lowering of the $\mathrm{c}^{13}$-content in the 
organic residue, while a $C^{13}$-enriched $\mathrm{CO}_{2}$ is simultaneously released. And finally, isotope exchange reactions, for instance, between carbon dioxide and methane, may produce fractionation effects. The isotopic equilibrium constants for such simple systems can be calculated by means of spectroscopical data and techniques of statistical mechanics, e.g. $\underline{5}$ 14/ 37!.

\section{Coal}

Coal is a product of former plant debris that has undergone severe physical and chemical alteration throughout geological history. For chemical-structural reasons, lignin is regarded the predominant biochemical starting material for all coals. In essence, the bulk of the carbon is organized in aromatic nuclei which contains mainly benzene, naphthalene, diphenyl, and phenanthrene, or their multiples. A substantial fraction of the non-aromatic carbon is arranged in hydroaromatic rings.

Figure 8

In view of the extensive diagenetic alteration, it is quite remarkable, that this process has not left any recognizable imprint in the $\delta C^{13}$ of various coals. There is absolutely no correlation between isotopic composition, degree of coalification, and geologic age of the coals (Fig. 8). The data fall close to the mean of wood $\delta c^{13}$ of -25 per mil, e.g. $-5 /$ 38/ 39/. It appears, therefore, reasonable to assume that no isotopic fractionation occurs during diagenesis, and that the former land plants had essentially the same isotopic composition as modern wood specimens. To further underline this conception, $\delta C^{13}$ data on thermo-metamorphosed Tertiary coals are presented in Figure 9. 
Figure 9

Gases, that have been generated during the coalification include principally methane and carbon dioxide. Relative to coal, methane is highty enriched in $\mathrm{C}^{12}$, in contrast to $\mathrm{CO}_{2}$ which contains more $\mathrm{C}^{13}$. In view of the uniform carbon isotope distribution in coals of all ranks, types, and ages, one has to assume that the isotopic composition of the aromatic coal structure is inherited without isotopic fractionation from former lignin precursors. It atso implies that, whatever happens during coalification, particularly in terms of $\mathrm{CO}_{2}$ and methane production, the enrichment in $\mathrm{C}^{13}$ in one compound must be matched by a decrease in $\mathrm{C}^{12}$ in the other.

\section{Petroleum and gases}

Most crude oil reservoirs occur in sediments which were deposited under marine conditions. This was generally interpreted to mean, that marine organisms represent the principal source for petroleum. With the advance of carbon isotope biogeochemistry, this geologically reasonable interpretation was partly abandoned in favor of a new hypothesis which assumes large contributions of organic matter from land. In the following discussion, however, we will present isotope information that agrees with well-rooted principles of geology, i.e. $\delta C^{13}$-values are constant with a marine origin for most petroleum occurences.

Figure 10 
In this connection, a comparison of present-day marine plankton and crude oil is quite revealing. Analogous to the coal-wood relationships, there is principally no isotope difference established between petroleum and its proposed biological source (Fig. 10). The range of all crude oils is identical to the range observed in marine plankton. This is particularly so, if one considers lipid compounds as a major precursor of hydrocarbons. Recent biological hydrocarbons and fatty acids obtained from marine plankton (Blumer, pers. communication) fall in the $\delta C^{13}$ range of -25 to -26 , which is exactly the mean of all crude oils.

An interesting age relationship can be recognized. This phenomenon, of course, may partly be due to biassed sampling, but the pattern exhibits some sort of trend which may be related to biogeochemical processes. We have previously seen that water temperature and respiration characteristics control the carbon isotope composition of marine plankton. The isotope variations observed in Figure 10 may thus be simply a function of paleotemperature fluctuations or perhaps due to changes in the length of day during earth history. There is an alternative interpretation. Inasmuch as the proportions of the various dissolved carbonate species in the sea are $\mathrm{pH}$ dependant, even a slight change in the atmospheric $\mathrm{CO}_{2}$ pressure will be reflected in the $\mathrm{HCO}_{3}{ }^{-}+\mathrm{CO}_{3}{ }^{-2}+$ dissolved $\mathrm{CO}_{2}$ relationships established in the ocean. Consequently, phytoplankton may utilize either dissolved $\mathrm{CO}_{2}$, bicarbonate, or a mixture of both. One may tentatively suggest that at low $\mathrm{pH}$, dissolved $\mathrm{CO}_{2}$ is the principal inorganic carbon extracted during photosynthesis, whereas at high $\mathrm{pH}$ bicarbonate or perhaps $\mathrm{CO}_{3}^{-2}$ will be utilized. The maximum $\delta C^{13}$ differences would amount to 7 per mil. 
The primary factors that control the isotopic carbon variation in naturally occuring gases liberated from organic matter is determined by the strength of therminal carbon-carbon bonds, the diagenetic temperature, and the maturity of the parent material[6/. At temperatures below $100^{\circ} \mathrm{C}$. the carbon isotope fractionations in methane are considerable namely, 60 to 80 per $\mathrm{mil}$; these values are in the same range as the bacterial $\mathrm{CH}_{4}$ fractionation data obtained during the fermentation of methanol $40 /$.

Interpretations of carbon isotope values in methane, however, are complicated by the fact that the gas may isotopically equilibrate with $\mathrm{CO}_{2}$ which commonly is highly enriched in $C^{13}$. The isotope exchange reaction can be written:

$$
\mathrm{C}^{12} \mathrm{O}_{2}+\mathrm{C}^{13} \mathrm{H}_{4} \rightleftharpoons \mathrm{C}^{13} \mathrm{O}_{2}+\mathrm{C}^{12} \mathrm{H}_{4}
$$

Following equations developed by Craig $\underline{5}$, and assuming that isotope equilibrium is established in this system, effective temperatures can be computed. Since the kinetics of this exchange are unknown, equilibrium considerations are very difficult, e.g. $18 / 41 / 42 /$.

In conclusion, the carbon isotope data in crude oils are consistent with the geological consensus that the biological source material for petroleum is predominantly of marine origin. Age differences are attributed to a number of influences which include fluctuations in water temperature, photosynthetic $\mathrm{CO}_{2}$ fixation mechanisms, or $\mathrm{pH}$ effects. The general trend of increasing paraffinicity with depth of burial or time, may also be responsible for some of the variation in $\delta C^{13}$. The $\delta C^{13}$ in methane and $\mathrm{CO}_{2}$ liberated in the course of petroleum formation, coalification, or kerogenisation, is dependant on reaction rate differences and isotope exchange equilibria. 
3. Kerogen

Most fossil organic matter is found in shales, slates, and schists. The quantity carried in sandstones and 1 imestones is comparatively small. In unmetamorphosed sediments, the term kerogen is frequently used for the bulk of the finely disseminated organic matter insoluble in organic solvents; in metamorphosed sediments, the organic compounds are more commonly named graphite.

Chemically, kerogen appears to be a denatured form of humic acid. The loss in oxygen and nitrogen, and the gain in carbon when compared to humic acids can essentially be linked to dehydration, decarboxylation, loss of methoxyl and carbonyl groups, and deaminiation phenomena. Due to the resulting increase in aromatic structures, kerogen becomes similar to coal, and in the final stage, the organic residue will resemble graphite.

Figure 11

The carbon isotope composition of all ancient sediments of fresh water and marine origin is close to -26 , except for early Precambrian samples that show more negative $\delta C^{13}$ values (Fig. 11). This relationship may mean that environmental conditions in Precambrian time were somewhat different from those established during later geological periods. In this connection, it is noteworthy that marine chemautotrophs exhibit the same degree of $c^{13} / c^{12}$ difference to phytoplankton, as Precambrian rocks show to Paleozoic and younger sediments. Since these chemautotrophs are considered the most likely precursors of photosynthetic plants, $\delta C^{13}$ differences between Precambrian and younger rocks may possibly be explained this way. In all instances, however, any of these tentative interpretations are highly speculative and therefore should be taken cum grano salis. 
It was mentioned previously that marine lipids are spread over a wide $\delta C^{13}$ range. Actually, however, significant $\delta C^{13}$ differences to the organism as a whole are only found in those cases, where the lipid content is small. Since in general marine plankton has a high fat content (about 20 to 40 percent), isotope differences to the total plankton become small for reasons which have previously been outlined. In this manner, the observation of Eckelman et al. $\underline{43 /}$ and Krejci-Graf and Wickman $\frac{44 /}{\text {, who }}$ found that crude oils and their associated shales have essentially the same isotopic composition, may find its explanation.

Similar to coals, the finely disseminated organic matter in sediments appears to be isotopically unaffected in the course of diagenesis once the early microbiological stage has passed. Even metamorphosis does not change the isotope pattern of the carbonaceous material in a significant way as was clearly demonstrated in studies on metamorphosed and unmetamorphosed sediments from otherwise geologically identical samples and settings 6 / 38/ 45/.

\section{PRIMORDIAL CARBON}

$\underline{\text { Igneous rocks }}$

There are several ways to obtain information on the $\delta C^{13}$ of primordial terrestrial carbon. One approach is a study of carbon associated with igneous rocks. The other alternative involves a comparison of the $\delta C^{13}$ in gases associated with thermal areas. In doing so, a controversial picture is obtained (Fig. 12). Namely, one set of data suggests a $\delta^{13}$ of about -4 to -8 , whereas another set of data indicates a $\delta C^{13}$ of about -23 for the primordial carbon isotope composition. However, the basalts, on which 
the figure of -23 was obtained, are possibly contaminated with biogenic carbon $5 /$. Therefore, an independant check by another method is advisable.

Table 1

In Table 1, the carbon content in various biological and geological materials is presented together with their mean $\delta C^{13}$. It is apparent that limestones and shales represent the only major exogenic sinks which take care of magmatic carbon released during earth history. Taking the relative proportions of carbonate and shale carbon into consideration, one can easily estimate the $\delta C^{13}$ of their common source. $A \delta C^{13}$ value of -7 relative to PDB standard is obtained. In view of the close agreement between geological estimates which are based on the relative abundance of shales, limestones and sandstones, and the geochemical carbon balance (Table 1), a $\delta C^{13}$ of -23 for magmatic carbon as inferred from basalts becomes rather unlikely. Instead, carbonatites, certain graphites, diamonds, and carbon dioxide from thermal areas appear to be the closest representatives of magmatic carbon (Fig. 12).

Figure 12

Unfortunately, little is known on the carbon isotope, distribution in magmatic rocks, and studies in this direction are worth pursuing. For instance, granites are supposed to have formed by crustal melting (anatexis); if sediments have been granitized this way, this characteristic may still be reflected in the $\delta C^{13}$ of carbon in granite. 
Meteorites

Meteoritic carbon falls into three discrete groups, yet a certain trend is noticeable (Fig. 13) i.e. the materials most enriched in carbon have in general the highest $\delta C^{13}$ values $50 / 51 /$. Carbonaceous chondrites (Type I) have a mean $\delta C^{13}$ that corresponds with terrestrial magmatic carbon, whereas normal chondrites fall into the range of land plants.

Figure 13

In following a concept developed by Mason $\frac{49 /}{-}$ and others, it is conceivable that carbonaceous chondrites (Type I) represent primitive materials, perhaps aggregates of dust from the primordial solar nebula, from which other chondrites were formed by a thermal metamorphism. This would result in partial or complete loss of volatile compounds and a lowering of the carbon content. Such a loss may be accompanied by isotope fractionation of the kind observed in Figure 13.

In this context, the observation by clayton $52 /$, showing an about 60 per mil enrichment in $\mathrm{C}^{13}$ in meteoritic dolomites over the associated organic carbon, is quite revealing. This fractionation is in the right direction, if we assume that a decarboxylation mechanism yielded a $\mathrm{CO}_{2}$ enriched in $\delta C^{13}$ which subsequently was used as a source in the dolomite formation. One may also propose that, different from earth, the production of organic carbon exceeded by far the formation of carbonates, which actually came late in the history of the carbonaceous chrondrites. That is at a time when the residual carbon pool may already have been highiy enriched in $\mathrm{C}^{13}$, due to a slight preference of $\mathrm{C}^{12}$-extraction during the inorganic synthesis of carbon-containing molecules. So far, dolomites 
are only known from carbonaceous chondrites, and in all probability a cause and effect relationship between organic matter and carbonates may be anticipated.

Many papers have appeared recently which assume a biogenic origin for the organic matter contained in carbonaceous chondrites. The idea has even been put forward that photosynthetic organisms were principally involved in the production of this extraterrestrial organic material. Here is not the place to review these claims critically, but the close agreement between the $\delta C^{13}$ in terrestrial magmatic carbon and in the Type 1 carbonaceous chondrite should make everybody aware that isotope data do by no means support such inference, but that they are more in line with an abiotic origin of meteoritic carbon.

\section{SUMMARY}

Al1 isotope information pertinent for the reconstruction of the carbon cycle in nature have been summarized in Figure 14 . We postulate a $\delta C^{13}$ of -7 for the magmatic carbon source. This is essentially the same isotope composition presently displayed in the atmosphere. In this way, significant amounts of carbon contributions by volcanic gases will only change the partial $\mathrm{CO}_{2}$ pressure and eventually the $\mathrm{pH}$ in sea water, but not the isotope composition of atmosphere and hydrosphere.

The uniform isotope ratios for all post-Precambrian carbonates and organics can only mean that we are dealing with a rather delicate biochemical system, where the production of organic matter and the formation of limestones is in a well-balanced state. From the wider range in the isotope composition of Precambrian organic matter, we may infer that the carbon cycle was still in a state of flux and thus in "disequilibrium." 
Figure 14

Diagenesis and metamorphosis will not alter the isotope composition of the organic matter to a large extent. A complete melting and exchange with magmatic carbon is required to erase the isotope record which principally was fixed during photosynthesis.

\section{ACKNOWLEDGMENTS}

This research represents part of a program at the Woods Hole Oceanographic Institution concerned with the stable isotope distribution in geological and biological systems, headed by John M. Hunt. His advice and encouragement in the course of this endeavour is gratefully acknowledged. I wish to express sincere appreciation to my biological colleagues at the Institute in particular, John H. Ryther, H. G. Trüper, S. W. Watson, J. A. Hellebust, and R. R. L. Guillard who stimulated and guided the research efforts in discussions and by active participation. To D. W. Spencer, I extend my gratitude for critically reading the manuscript and to $\mathrm{J}$. Matheja for advice in the presentation of the data.

The work was sponsored by the National Aeronautics and Space Administration and by a grant from the Petroleum Research Fund administered by the American Chemical Society. Grateful acknowledgment is hereby made to NASA and the donors of said fund.

\section{APPENDIX}

This chapter comprises a collection of all carbon isotope data which have been used in the preceeding discussion. The more than 5000 individual 
analyses have been grouped in such a way as to facilitate a convenient comparison of the various samples (Figs. 15-21). The list of publications from which the isotope data were obtained include more than 400 titles. The author regrets that due to lack of space no proper credit can be given here to all sources of information. A complete list of references, however, may be obtained by writing to the author.

Figures 15 to 21 


\section{REFERENCES}

1. Urey, H. C. The thermodynamic properties of isotopic substances. J.Chem. Soc., 1947, 562-581 (1947).

2. Nier, A. 0. A mass spectrometer for isotope and gas analysis. Rev. Sci. Instr., 18, 398-411 (1947).

3. Mckinney, C. R., J. M. McCrea, S. Epstein, H. A. Allen, and H. C. Urey. Improvements in mass spectrometers for the measurement of small differences in isotope abundance ratios. Rev. Sci. Instr., 2l, 724-730 (1950).

4. Baertschi, P. Die Fraktionierung der natürlichen Kohlenstoffistopen im Kohlendioxydstoffwechsel grüner Pflanzen. Helv. Chim. Acta, 36, 773-781 (1953).

5. Craig, H. The geochemistry of stable carbon isotopes. Geochim. et Cosmochim. Acta, 3, 53-92 (1953).

6. Landergren, S. On the relative abundance of the stable carbon isotopes in marine sediments. Deep Sea Research, 1 , 98-120 (1954).

7. Nier, A. 0. and Gulbransen, E. A. Variation in the relative abundance of the carbon isotopes. J. Amer. Chem. Soc., 6], 697-698 (1939).

8. Rankama, K. New evidence of the origin of pre-Cambrian carbon. Bul1. Geol. Soc. Amer., 59, 389-416 (1948).

9. West, S. S. Relative abundance of the carbon isotopes in petroleum. Geophysics, 10, 406-420 (1945).

10. Wickman, F. E. Variations in the relative abundance of the carbon isotopes in plants. Geochim. et Cosmochim. Acta, 2, 243-254 (1952).

11. Park, R., and S. Epstein. Carbon isotope fractionation during photosynthesis. Geochim. et Cosmochim. Acta, 21, 110-126 (1960).

12. Park, R. and S. Epstein. Metabolic fractionation of $C^{13}$ and $C^{12}$ in plants. Plant Physiol., 36, 133-138 (1961).

13. Abelson, P. H. and T. C. Hoering. Carbon isotope fractionation in formation of amino acids by photosynthetic organisms. Proc. Nat. Acad. Sci. U.S., 47, 623-632 (1961).

14. Bigeleisen, $\mathrm{J}$. The relative reaction velocities of isotopic molecules. J. Chem. Phys., 17, 675-678, (1949). 
15. Silverman, S. R. Investigations of petroleum origin and evolution mechanisms by carbon isotope studies. In "Isotopic and Cosmic Chemistry" eds. H. Craig, S. L. Miller, and G. J. Wasserburg, North-Holland Publishing Company, Amsterdam, 92-102 (1964).

16. Sackett, W. M., S. Nakaparksin, and D. Dalrymple. Carbon isotope effects in methane production by thermal cracking. Third Intern. Meet. Org. Geochem., London, Sept., 1966.

17. Sackett, W. M., and R. R. Thompson. Isotopic organic carbon composition of recent continental derived clastic sediments of eastern gulf coast, Gulf of Mexico. Bul1. Amer. Assoc. Petrol. Geol., 47, 525-528 (1963).

18. Zartman, R. E., G. J. Wasserburg, and J. H. Reynolds. Helium, argon, and carbon in some natural gases. J. Geophys. Res., 66, 277-306 (1961).

19. Silverman, S. R. and S. Epstein. Carbon isotopic compositions of petroleums and other sedimentary organic materials. Bull. Amer. Assoc. Petrol. Geol., 42, 998-1012 (1958).

20. Keeling, C. D. The concentration and isotopic abundances of atmospheric carbon dioxide in rural areas. Geochim. et Cosmochim. Acta, 13, 322334 (1958).

21. Craig, H. Isotopic standards for carbon and oxygen and correction factors for mass spectrometric analys is of carbon dioxide. Geochim. et. Cosmochim. Acta, 12, 133-149 (1957).

22. Calvin, M. and J. A. Bassham. "The Photosynthesis of Carbon Compounds." W. A. Benjamin, Inc., New York (1962).

23. Bassham, J. A. Photosynthesis: The path of carbon. In "Plant Biochemistry" eds. J. Bonner, and J. E. Varner, Academic Press, New York and London, 875-902 (1965).

24. Bonner, J. and J. E. Varner. "Plant Biochemistry" Academic Press, New York and London, 1054 pp..(1965).

25. Keeling, C. D. The concentration and isotopic abundances of carbon dioxide in the atmosphere. Tellus, 12,717-723 (1960).

26. Keeling, C. D. Concentration and isotopic abundances of carbon dioxide in rural and marine air. Geochim. et Cosmochim. Acta, 24, 299-313 (1961).

27. Vogel, J.C. and D. Ehhalt. The use of the carbon isotopes in groundwater studies. In "Radioisotopes in Hydrology" Intern. Atomic Energy Agency, Vienna, 383-395 (1963).

28. Münnich, K. 0. and J. C. Vogel. Untersuchungen an pluvialen Wässern der Ost-Sahara. Geol. Rundschau, $52,611-624$ (1962). 
29. Sackett, W. M., W. R. Eckelmann, M. L. Bender, and A. W. H. Be. Temperature dependence of carbon isotope composition in marine plankton and sediments. Science, 148, 235-237, (1965).

30. Craig, H. Carbon-13 in plants and the relation between carbon ${ }^{13}$ and carbon 14. J. Geol., 62, 115-149 (1954).

31. Degens, E. T., R. L. Guillard, W. M. Sackett, and J. A. Hellebust. Metabolic fractionation of carbon isotopes in marine plankton, Part I. (Submitted to Deep Sea Research).

32. Degens, E. T., M. Behrendt, B. Gotthardt, and E. Reppmann. Metabolic fractionation of carbon isotopes in marine plankton, Part II. (Submitted to Deep Sea Research.)

33. Parker, P. L. The isotopic composition of the carbon of fatty acids. Ann. Rep. Dir. Geophys. Lab. Carnegie Inst. Wash. Year Book 61, 187-190 (1961-62).

34. Campbe11, A. E., J. A. Hellebust, and S. W. Watson. Reductive pentose phosphate cycle in Nitrosocystis oceanus. J. Bacter., 91, 1178-1185 (1966).

35. Kaplan, I. R. and S. C. Rittenberg. Carbon isotope fractionation during metabol ism of lacate by Desulfovibrio desulfuricans. J. gen. Microbiol., 34, 213-217 (1964).

36. Oana, S. and E. S. Deevey. Carbon-13 in lake waters and its possible bearing on paleolimnology. Amer. J. Sci., 258-A, 253-272 (1960).

37. Craig, H. The isotopic geochemistry of water and carbon in geothermal areas. In "Nuclear Geology on Geothermal Areas," Consigl io Nazionale Delle Richerche, Pisa, 17-53 (1965).

38. Wickman, F. E. The cycle of carbon and the stable carbon isotopes. Geochim. et Cosmochim. Acta, 9, 136-153 (1956).

39. Compston, W. Carbon isotopic compositions of certain marine invertebrates and coals from the Australian Permian. Geochim. et Cosmochim. Acta, 18, $1-22(1960)$.

40. Rosenfeld, W. D. and S. R. Silverman. Carbon isotope fractionation in bacterial production of methane. Science, 130, 1659 (1959).

41. Wasserburg, G. J., E. Mazor, and R. E. Zartman. Isotopic and chemical composition of some terrestrial natural gases. In "Earth Science and Meteoritics" eds. J. Geiss, and E. D. Goldberg, North-Holland Publishing Company, Amsterdam, 219-240 (1963).

42. Nakai, N. Carbon isotope fractionation of natural gas in Japan. J. Earth Sci., $8,174-180$ (1960). 
43. Eckelmann, W. R., W. S. Broecker, D. W. Whitlock, and J. Allsup. Implications of carbon isotope composition of total organic carbon of some recent sediments and ancient oils. Bul1. Amer. Assoc. Petrol. Geol., 46, 699-704 (1962).

44. Krejci-Graf, K., and F. E. Wickman. Ein geochemisches Profil durch den Lias alpha (zur Frage der Entstehung des Erdöls). Geochim. et Cosmochim. Acta, 18, 259-272 (1960).

45. Gavelin, S. Variations in isotopic composition of carbon from metamorphic rocks in Northern Sweden and their geological significance. Geochim. et Cosmochim. Acta, 12 297-314 (1957).

46. Borchert, H. Zur Geachemie des Kohlenstoffs. Geochim. et Cosmochim.Acta, 2. 62-75 (1951).

47. Ryther J. H. Organic production by plankton algae and its environmental control. In "The Ecology of Algae" Symposium held at the Pymatuning Laboratory of Field Biology, University of Pittsburgh, Spec. Pub. No. 2, 72-83 (1959).

48. Weeks, L. G. Habitat of oil and factors that control it. In "Habitat of $0 i 1 "$ ed. L. G. Weeks, Tulsa Ok1ahoma, Amer. Assoc. Petrol. Geol, 1-61 (1958).

49. Mason, B. The carbonaceous chondrites. Space Science Review, $1,621-646$ (1962-1963).

50. Boato, G. The isotopic composition of hydrogen and carbon in the carbonaceous chondrites. Geochim. et Cosmochim. Acta, 6, 209-220 (1954).

51. Briggs, M. H. Evidence of an extratemporal origin for some organic constituents of meteorites. Nature, 197, 1290 (1963).

52. Clayton, R. N. Carbon isotope abundance in meteoritic carbonates. Science 140, 192-193 (1963). 
TABLE 1

BIOGEOCHEMICAL BALANCE OF CARBON $46 / 47 / 48 /$

Carbon

$\delta C^{13}$

Carbonates (calcite + dolomite)

2340

0

Shales and Sandstones

633

$-26$

Coals

1.1

$-25$

Petroleum

0.035

$-26$

Ocean $\left(\mathrm{HCO}_{3}{ }^{-}+\mathrm{CO}_{3}{ }^{-2}+\right.$ dissolved $\left.\mathrm{CO}_{2}\right)$

7.5

0

Atmospheric $\mathrm{CO}_{2}$

0.125

$-7$

Living matter (land)

0.054

$-25$

Living matter (marine)

0.00005

$-20$

Mean (magmatic carbon)

* gram per square centimeter earth surface 


\section{LIST OF FIGURES}

Figure 1 Carbon combustion apparatus $-\underline{16 /}$. Legend: $D=$ acetone-dry ice trap; $N_{1}, N_{2}=$ Tiquid nitrogen traps; $P_{1}, P_{2}, P_{3}=$ to mechanical pump; $S=$ tube equipped with break seal for thermal cracking studies; $S T=$ carbon dioxide transfer tube; $T_{1} T_{2}=$ thermocouple pressure gauge.

Figure 2 Respiration effects in laboratory cultured marine plankton $31 /$. Figure 3 Temperature effects in laboratory cultured marine plankton $\frac{31 /}{}$. Figure $4 \delta C^{13}$ in various biochemical constituents isolated from marine plankton $\frac{321}{2}$. For comparison, the $\delta C^{13}$ in representative recent and ancient sediments is included.

Figure $5 \delta C^{13}$ in living matter.

Figure 6 Isotopic composition of organic carbon in Recent Gulf Coast sediments $17 /$.

Figure 7 Isotopic composition of organic carbon in Recent sediments (unpublished data, J. M. Hunt, K. 0. Emery).

Figure $8 \delta C^{13}$ in coals of various geologic ages $\underline{5 / 38 / 39 /}$.

Figure 9 Relationship between $\delta C^{13}$ and carbon content in partly metamorphosed Tertiary lignites $38 /$.

Figure 10 Carbon isotope distribution in crude $0 i l s$ of various geologic ages.

Figure 11 Carbon isotope distribution in ancient sediments.

Figure 12 Carbon isotope distribution in various terrestrial and extraterrestrial materials.

Figure 13 Isotopic composition of organic carbon in meteorites $50 / 51 /$.

Figure 14 Flow diagram of carbon cycle in nature. 
Figure $15 \delta \mathrm{C}^{13}$ in living matter, atmospheric $\mathrm{CO}_{2}$, and dissolved carbonate species in fresh water and sea water.

Figure $16 \delta \mathrm{C}^{13}$ in various biochemical fractions extracted from marine plankton.

Figure $17, \delta C^{13}$ relationships in co-existing carbon-containing compounds from Recent lacustrine environments $\underline{36 /}$.

Figure $18 \delta C^{13}$ in Recent sediments.

Figure $19 \delta C^{13}$ in crude oils from various geologic ages.

Figure $20 \delta C^{13}$ in ancient sediments (top diagram) and coals (bottom diagram).

Figure $21 \delta C^{13}$ in various igneous, metamorphic, and meteoritic samples. 


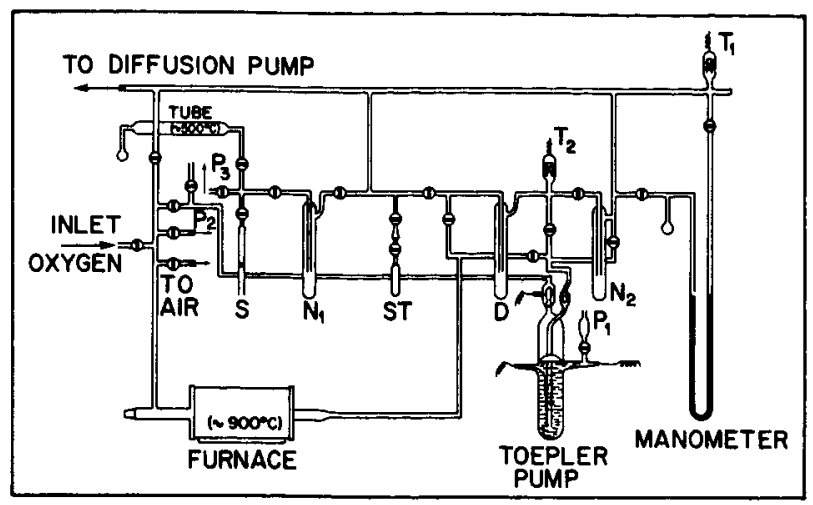

Figure 1

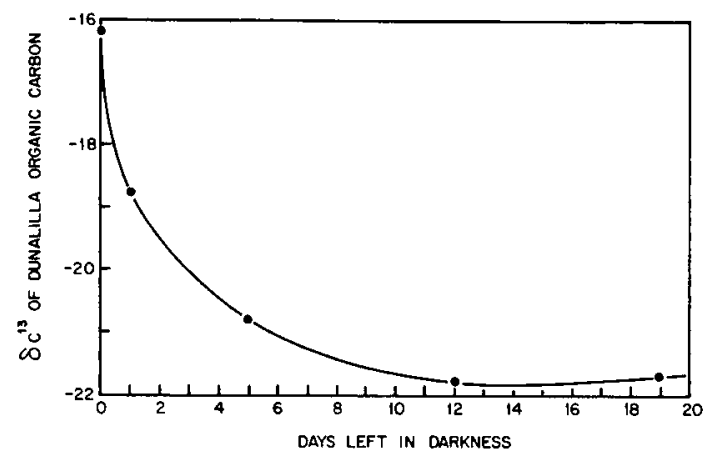

Figure 2

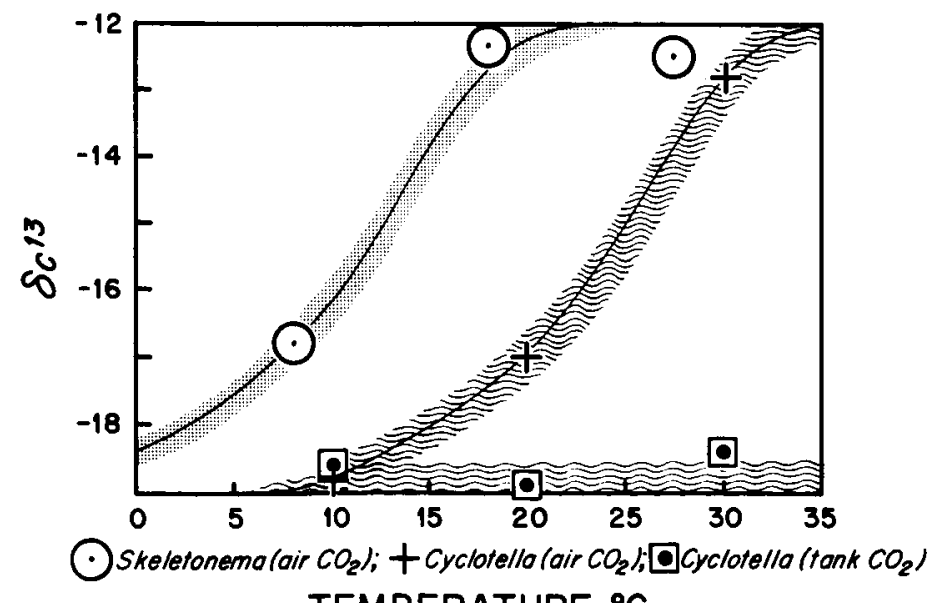

TEMPERATURE ${ }^{\circ} \mathrm{C}$

Figure 3 


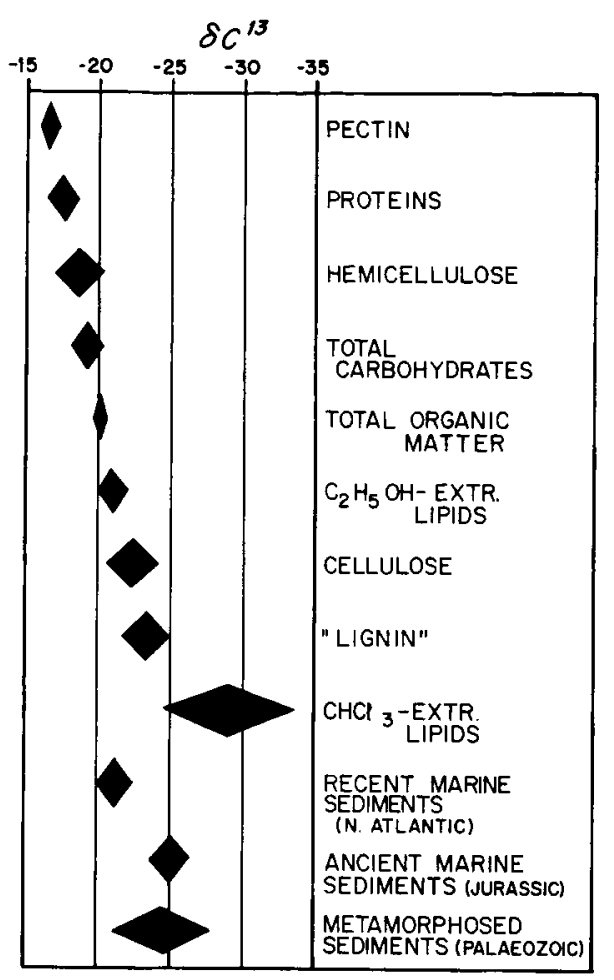

Figure 4

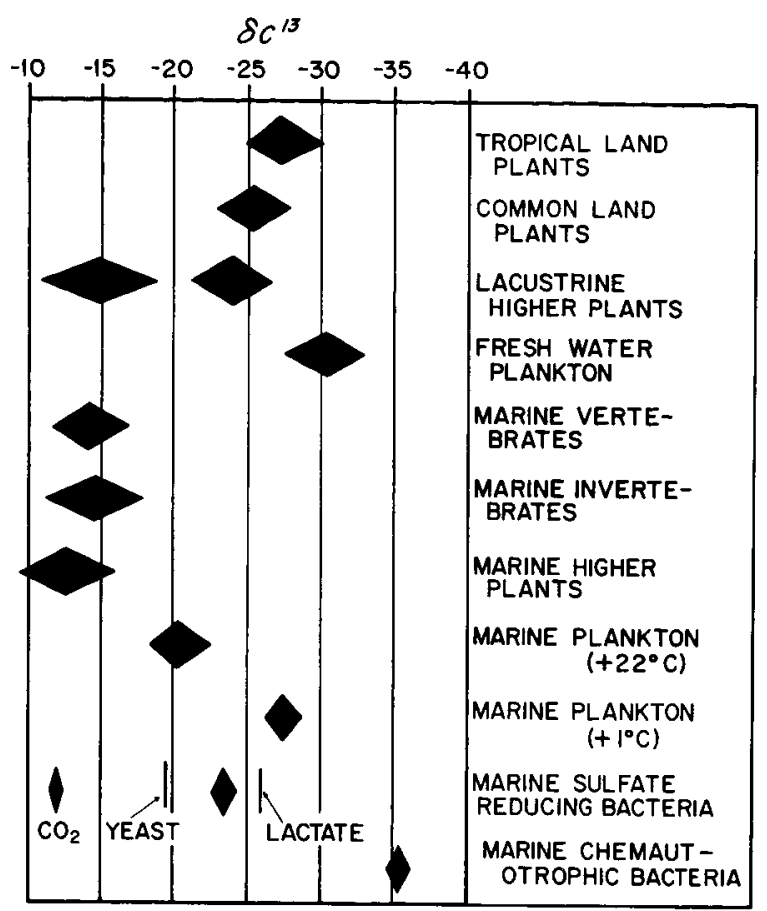

Figure 5

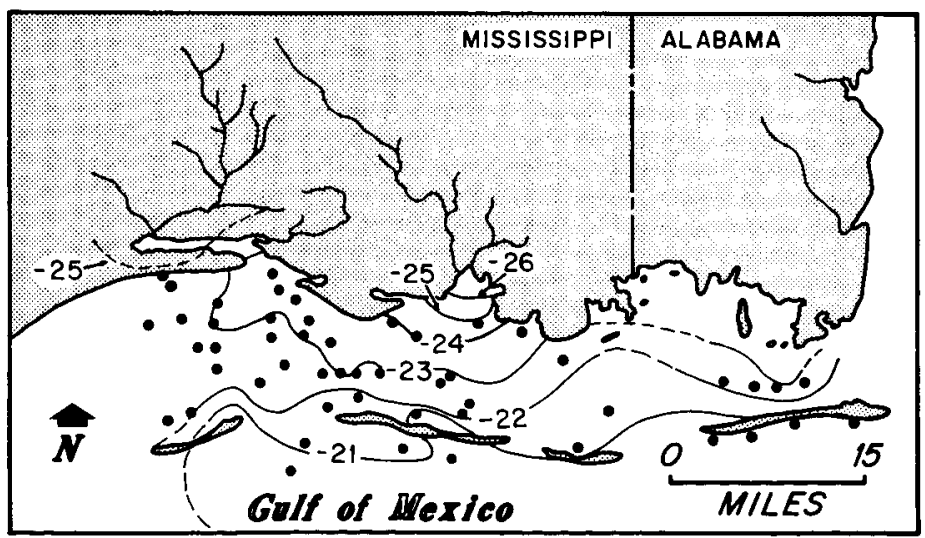

Figure 6 


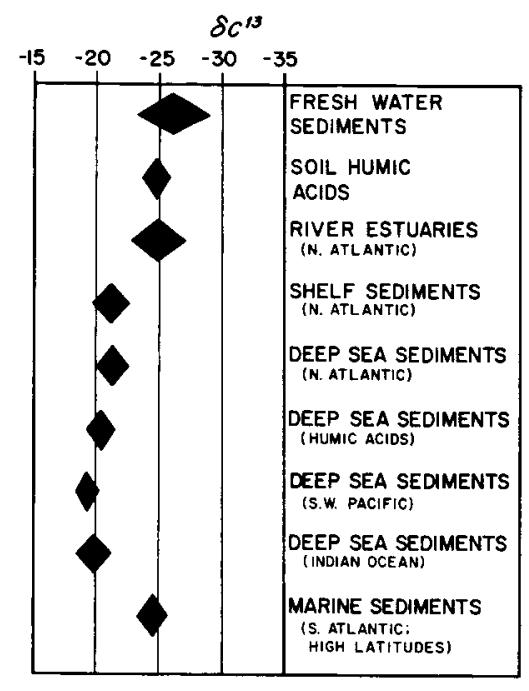

Figure 7

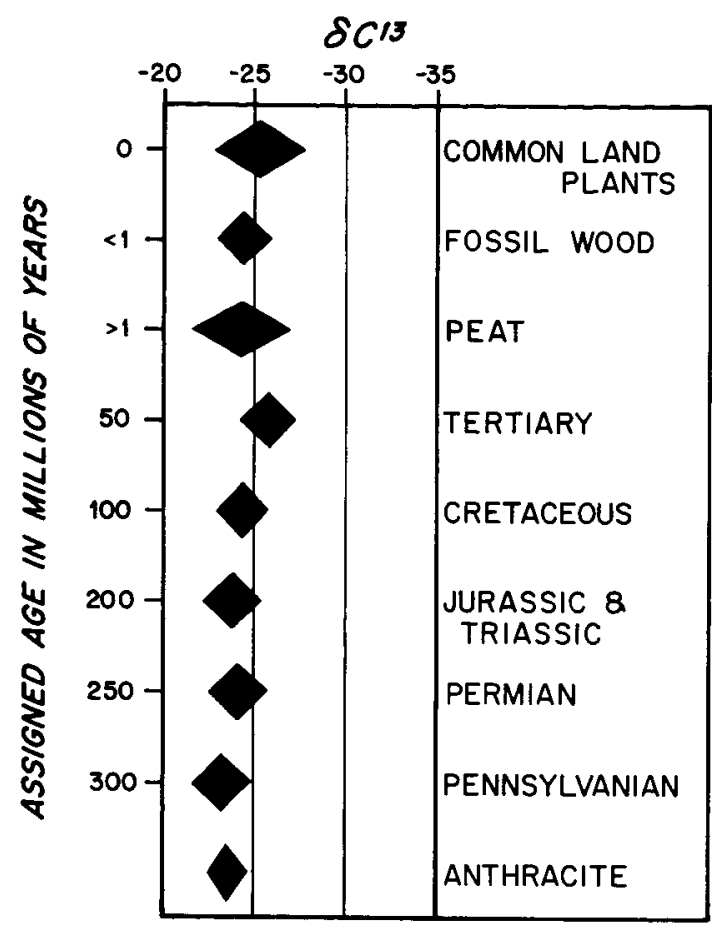

Figure 8

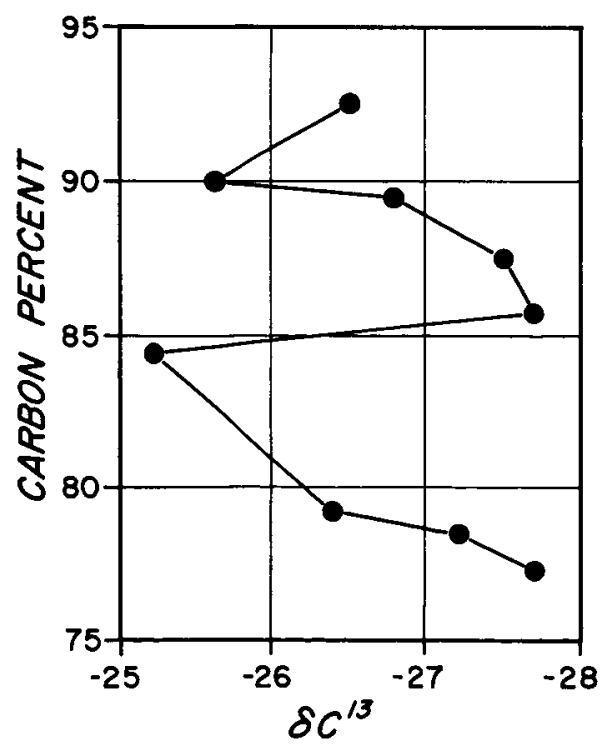

Figure 9 


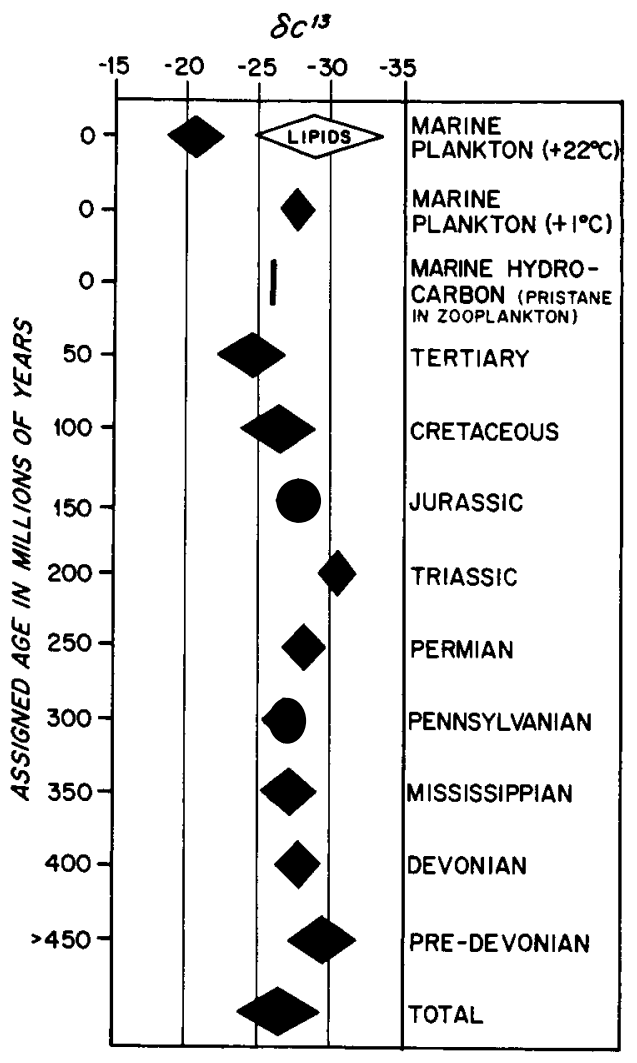

Figure 10

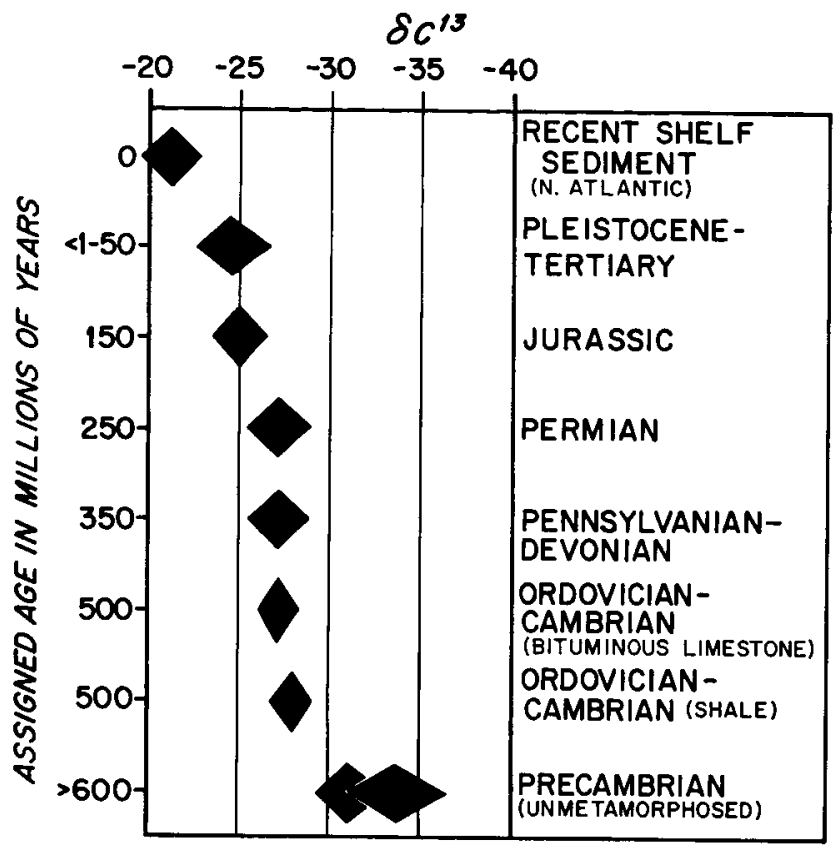

Figure 11

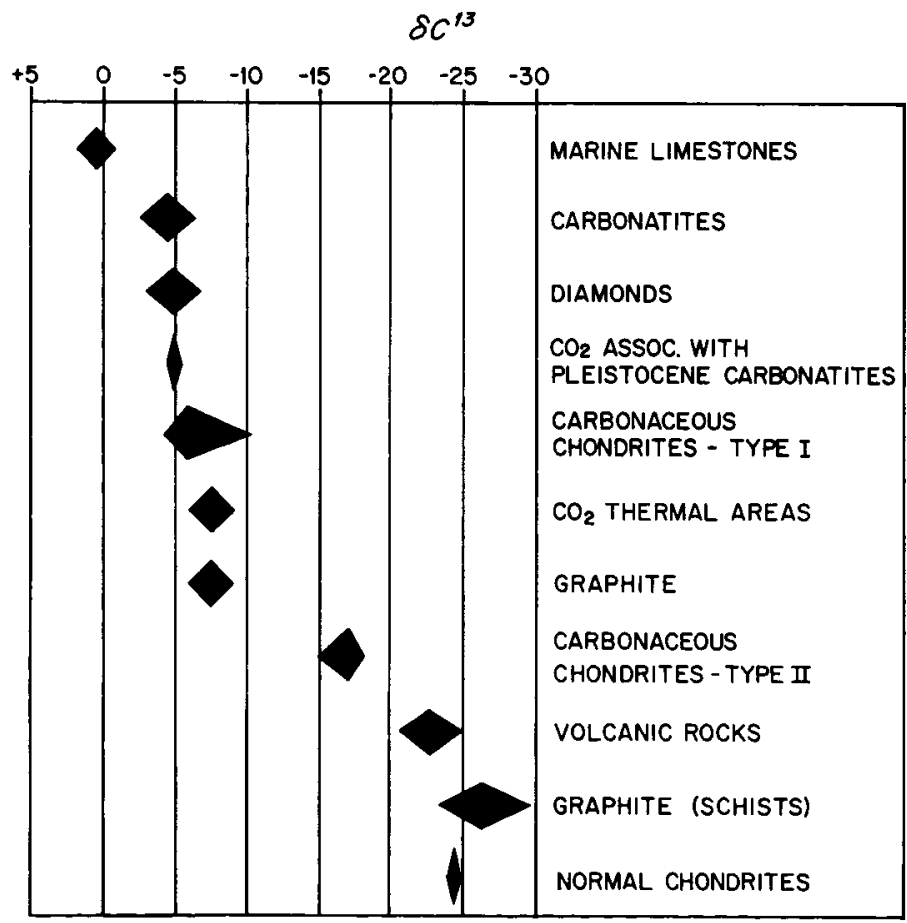

Figure 12 

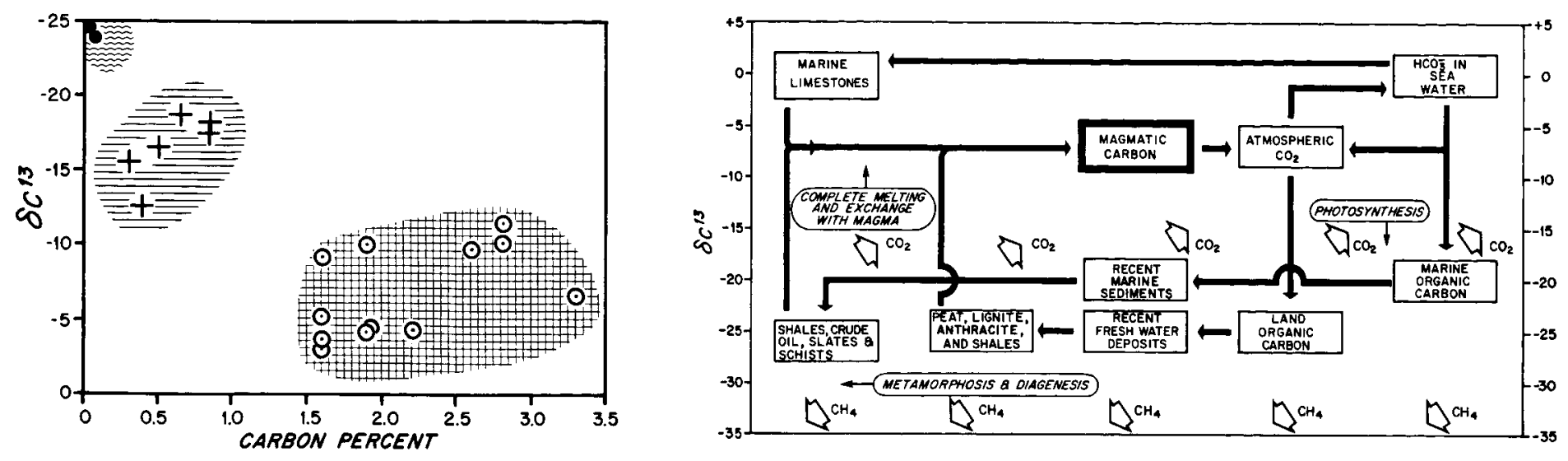

NORMAL CHONORITES CARBONACEOUS CHONDRITES

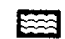
TYPE I TYPE II

Figure 14

Figure 13

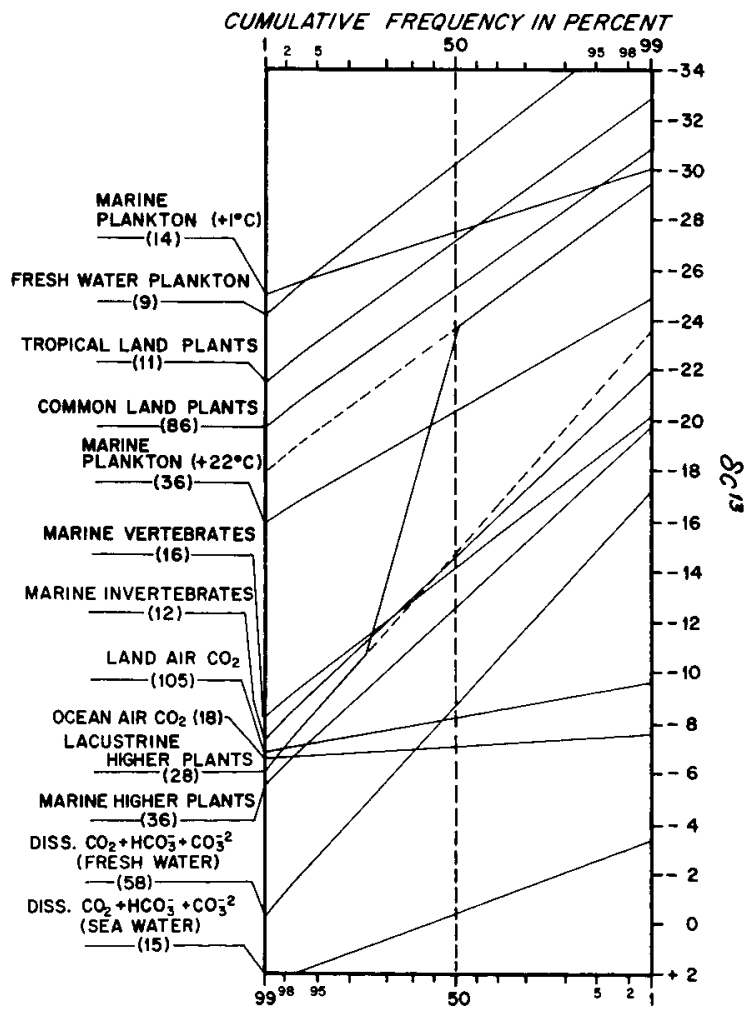

Figure 15 


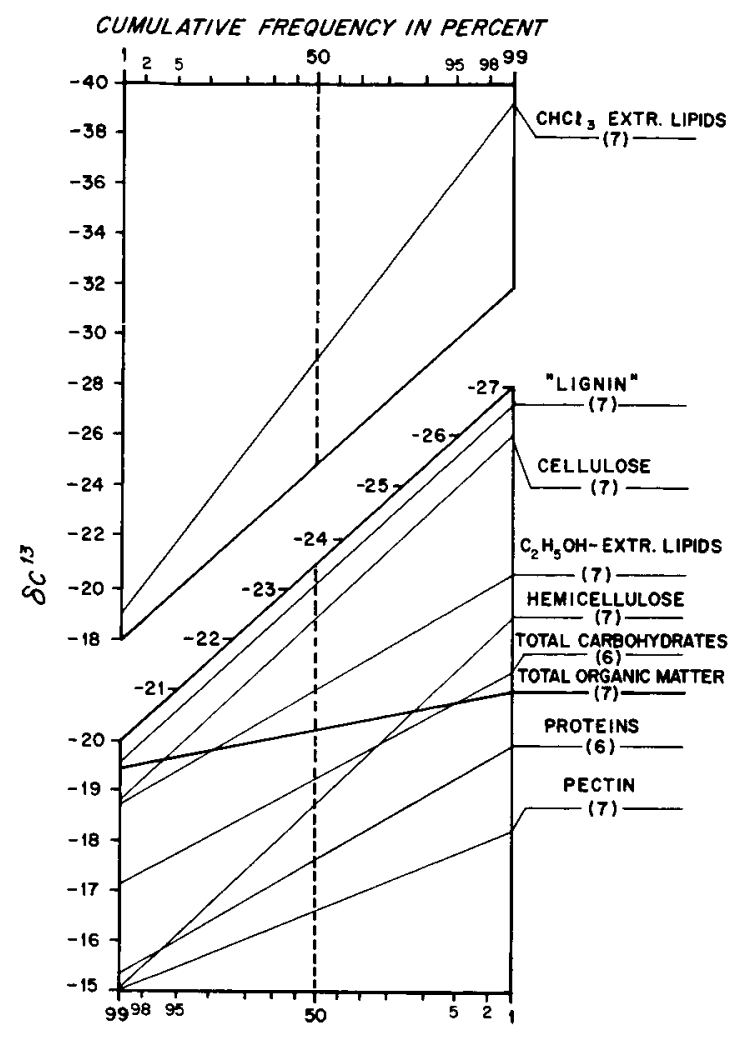

Figure 16

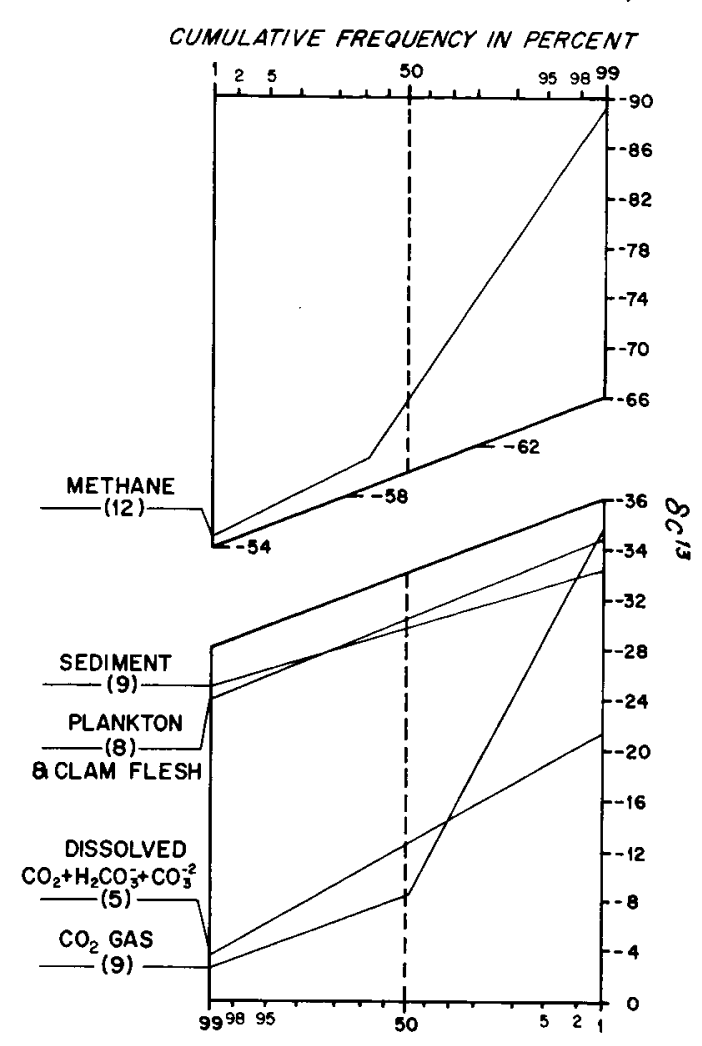

Figure 17

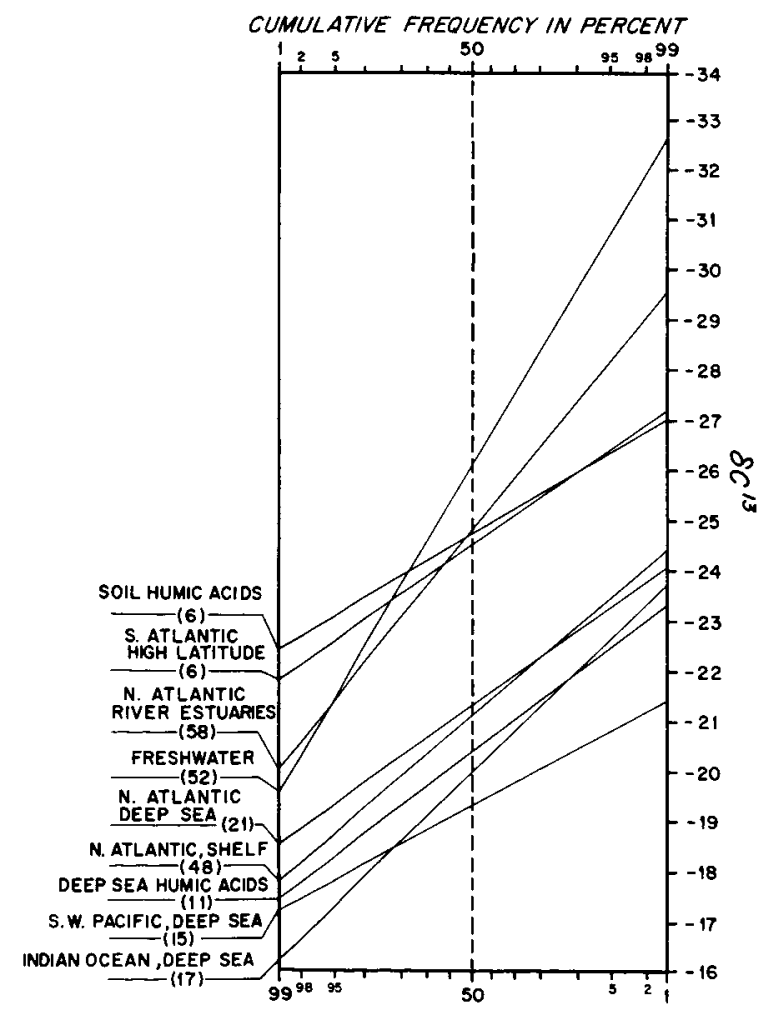

Figure 18 


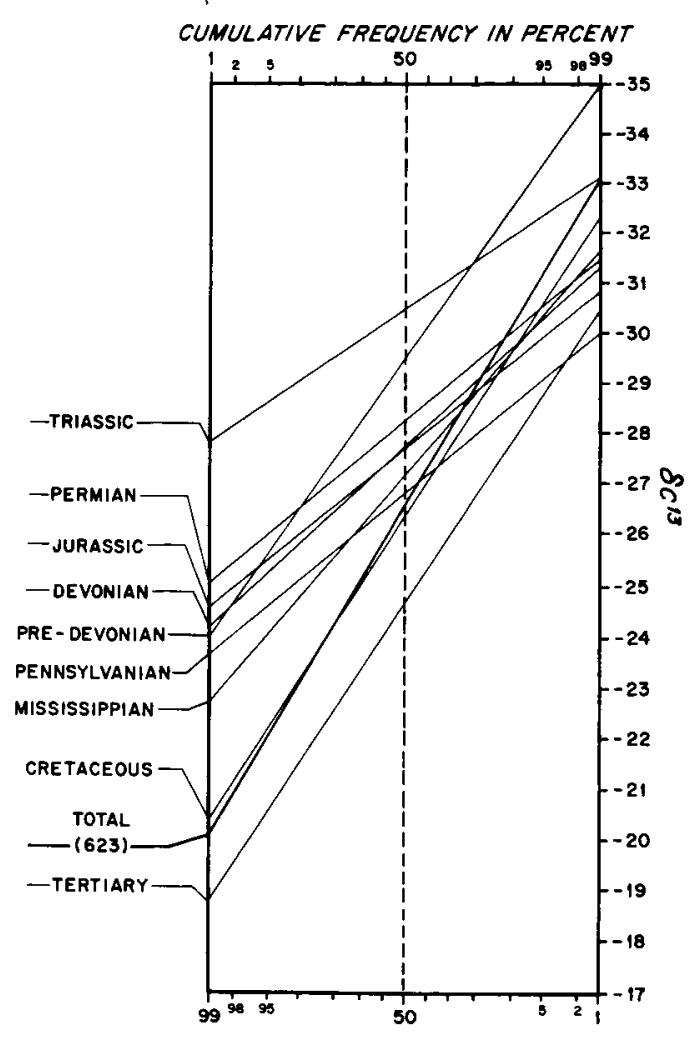

Figure 19

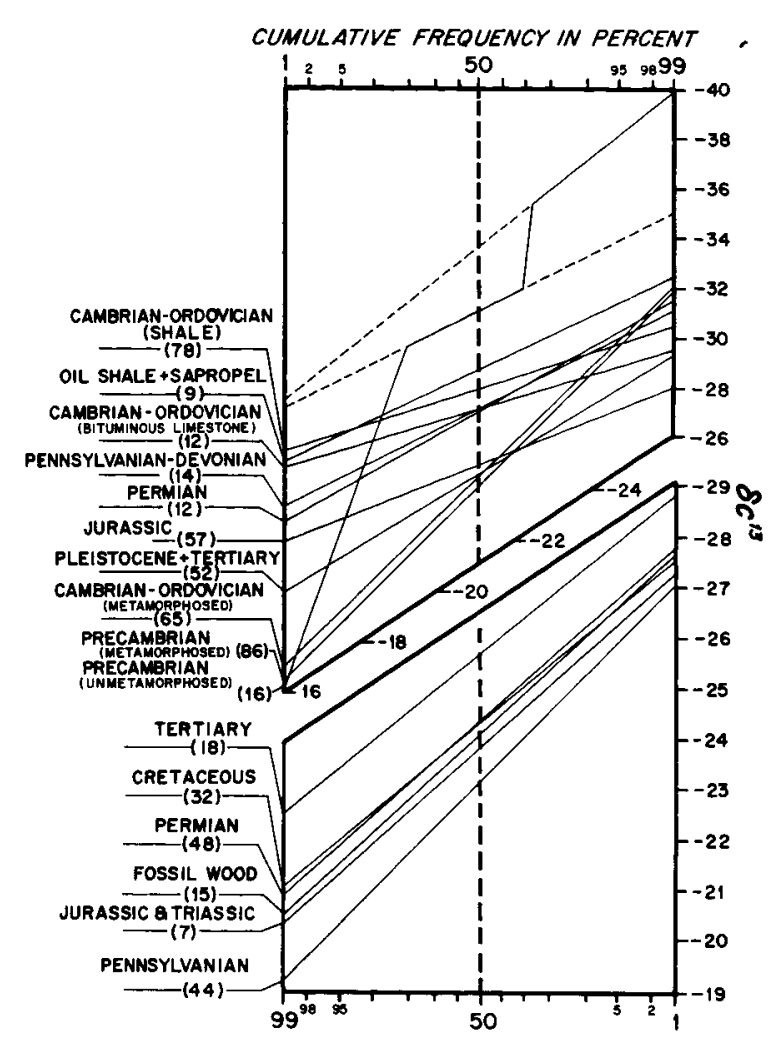

Figure 20

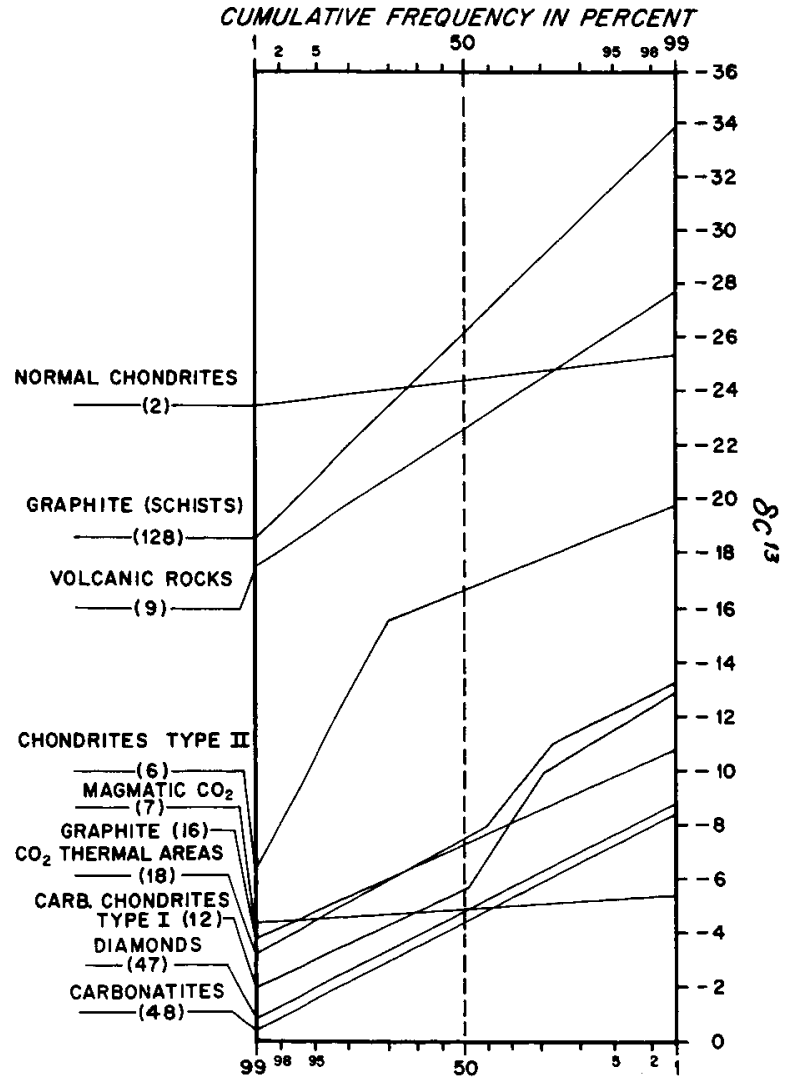

Figure 21 